\title{
ОСНОВНІ ПРОБЛЕМИ ПОКРАЩАННЯ ЗАБЕЗПЕЧЕННЯ СТУДЕНТІВ-МЕДИКІВ СУЧАСНОЮ НАВЧАЛЬНО-МЕТОДИЧНОЮ ЛІТЕРАТУРОЮ
}

\author{
І. С. Вітенко, І. В. Мельник, С. В. Штанько, Л. Г. Варнавська \\ Центральний методичний кабінет з вищої медичної освіти МОЗ Украйни

\section{THE MAIN PROBLEMS OF IMPROVEMENT OF SUPPLYING OF MEDICAL STUDENTS WITH THE MODERN EDUCATIONAL- METHODICAL LITERATURE} \\ I. S. Vitenko, I. V. Melnyk, S. V. Shtanko, L. H. Varnavska \\ Central Methodical Cabinet on Higher Medical Education of MPH of Ukraine
}

\begin{abstract}
У статті висвітлено проблеми покращання забезпечення студентів якісною навчальною літературою, проведено аналіз укомплектованості бібліотек вищих медичних навчальних закладів підручниками та посібниками, враховуючи сучасні вимоги.
\end{abstract}

The article deals with the problems of the improvement of student providing with comprehensive educational litetature. The literature supplying of the higher medical establishment libraries has been analysed taking into consideration the modern requirements.

Вступ. Україна сьогодні переживає значні економічні труднощі, що призводить до зменшення фінансування витрат на освіту, у тому числі і медичну. Як вже неодноразово нами зазначалось, важливою складовою в системі якісної підготовки фахівців для практичної охорони здоров'я є забезпечення студентів сучасними підручниками, посібниками, підготовленими відповідно до оновлених навчальних програм 3 дисциплін [1].

Основна частина. Указом Президента України від 30 жовтня 2010 року № 926/2010“"Про заходи щодо забезпечення пріоритетного розвитку освіти в Україні” (р. 3, п. 22) доручено Кабінету Міністрів України здійснити заходи щодо удосконалення порядку забезпечення навчальною літературою студентів вищих навчальних закладів.

Щорічний моніторинг забезпечення навчальних дисциплін підручниками та посібниками, що проводиться Центральним методичним кабінетом з вищої медичної освіти МОЗ України, свідчить, що станом на 1 вересня 2011 р. забезпечення підручниками становить $28 \%$, посібниками - 27 \% (табл. 1).

Таблиця 1. Забезпечення студентів підручниками та посібниками, виданими державною мовою з грифами МОН, МОЗ, ЦМК з ВМО МОЗ України

\begin{tabular}{|c|c|c|}
\hline Рік проведення обрахунків & Забезпечення підручниками (\%) & Забезпечення посібниками (\%) \\
\hline 2008 & 43 & 44 \\
\hline 2009 & 47 & 58 \\
\hline 2010 & 32 & 33 \\
\hline 2011 & 28 & 27 \\
\hline
\end{tabular}

Насторожує тенденція до поступового зменшення даних показників протягом останніх років.

Найменш забезпеченим підручниками та посібниками залишається блок гуманітарних та соціальноекономічних дисциплін - 17 \% підручниками та 23 \% посібниками (табл. 2).
При цьому найменш забезпечені оновленими підручниками та посібниками, підготовленими державною мовою, дисципліни, зазначені в таблиці 3.

Дещо краще забезпечені підручниками та посібниками професійно-орієнтовані дисципліни (у \%) (табл. 4).

() І. С. Вітенко, І. В. Мельник, С. В. Штанько, Л. Г. Варнавська 
Матеріали Всеукраїнської навчально-наукової конференції, присвяченої 55-річчю Тернопільського державного медичного університету імені І. Я. Горбачевського, “Впровадження нових технологій за кредитно-модульної системи організації навчального процесу у ВМ(Ф)НЗ III-IV рівнів акредитації”

Таблиця 2. Забезпечення підручниками та посібниками по блоках дисциплін

\begin{tabular}{|l|c|c|c|}
\hline & 2011 & 2010 & 2008 \\
\hline \multicolumn{4}{|c|}{ Гуманітарні та соціально-економічні дисципліни } \\
\hline Підручники \% & 17 & 16 & 30 \\
\hline Посібники \% & 23 & 31 & 39 \\
\hline \multicolumn{4}{|c|}{ Природничо-наукові дисципліни } \\
\hline Підручники \% & 33 & 43 & 58 \\
\hline Посібники \% & 26 & 37 & 44 \\
\hline \multicolumn{4}{|c|}{ Професійно-орієнтовані дисципліни } \\
\hline Підручники \% & 34 & 36 & 41 \\
\hline Посібники \% & 31 & 30 & 41 \\
\hline
\end{tabular}

Таблиця 3. Найменш забезпечені оновленими підручниками та посібниками такі дисципліни (у \%)

\begin{tabular}{|l|c|c|}
\hline \multicolumn{1}{|c|}{ Назва дисципліни } & Підручники & Посібники \\
\hline Цивільний захист & 0 & 0 \\
\hline Охорона праці в галузі & 5 & 7 \\
\hline Урологія & 7 & 28 \\
\hline Епідеміологія & 7 & 37 \\
\hline Офтальмологія & 8 & 8 \\
\hline Основи біоетики і біобезпеки & 9 & 29 \\
\hline Судова медицина & 10 & 10 \\
\hline БЖд основи охорони праці & 11 & 28 \\
\hline Патоморфологія & 11 & 7 \\
\hline Історія України & 12 & 33 \\
\hline Радіаційна медицина & 13 & 34 \\
\hline Догляд за хворими & 13 & 10 \\
\hline Медична інформатика & 14 & 22 \\
\hline Професійні хвороби & 14 & 23 \\
\hline Медичне законодавство & 14 & 42 \\
\hline Анестезіологія та інтенсивна терапія & 15 & 18 \\
\hline Історія медицини & 18 & 28 \\
\hline Екстрена та невідкладна медична допомога & 19 & \\
\hline
\end{tabular}

Таблиця 4. Найкраще забезпечені оновленими підручниками та посібниками такі дисципліни (у \%)

\begin{tabular}{|l|c|c|}
\hline \multicolumn{1}{|c|}{ Назва дисципліни } & Підручники & Посібники \\
\hline Хірургія & 86 & 80 \\
\hline Онкологія & 75 & 24 \\
\hline Медична психологія & 69 & 14 \\
\hline Медична генетика & 68 & 26 \\
\hline Гігієна та екологія & 67 & 38 \\
\hline Дерматологія, венерологія & 67 & 36 \\
\hline Внутрішня медицина & 66 & 83 \\
\hline Неврологія & 57 & 37 \\
\hline Акушерство і гінекологія & 56 & 57 \\
\hline Медична хімія & 56 & 23 \\
\hline Анатомія людини & 54 & 47 \\
\hline Біологічна та біоорганічна хімія & 52 & 43 \\
\hline Медицина надзвичайних ситуацій & 50 & 51 \\
\hline Клінічна фармакологія & 50 & 36 \\
\hline Загальна практика (сімейна медицина) & 48 & 40 \\
\hline Педіатрія & 47 & 80 \\
\hline Фтизіатрія & 45 & 47 \\
\hline
\end{tabular}


Як вже неодноразово Кабінетом наголошувалось, позитивні зрушення показників забезпечення студентів навчальною книгою можливі за умови збільшення у навчальних закладах видатків на видання та закупівлю навчальної літератури [2].
Незважаючи на відсутність державного фінансування видання навчальних книг для студентів-медиків, у більшості навчальних закладів адміністрацією знайдено кошти на видання навчальної літератури (табл. 5). Переважна кількість рукописів видана за рахунок авторських коштів.

Таблиця 5. Видавнича діяльність вищих медичних навчальних закладів України у 2011 році

\begin{tabular}{|c|c|c|c|c|c|c|c|}
\hline $\begin{array}{c}\text { Назва навчального } \\
\text { закладу }\end{array}$ & $\begin{array}{l}\text { Всього } \\
\text { видано }\end{array}$ & $\begin{array}{l}\text { Підруч- } \\
\text { ники }\end{array}$ & $\begin{array}{l}\text { Посіб- } \\
\text { ники }\end{array}$ & $\begin{array}{c}\text { Навч.- } \\
\text { метод. } \\
\text { посіб- } \\
\text { ники }\end{array}$ & $\begin{array}{c}\text { Елек- } \\
\text { тронні } \\
\text { видання }\end{array}$ & $\begin{array}{l}\text { Моно- } \\
\text { графії }\end{array}$ & $\begin{array}{c}\text { Метод. } \\
\text { рекомен- } \\
\text { дації, } \\
\text { вказівки }\end{array}$ \\
\hline $\begin{array}{l}\text { Буковинський державний } \\
\text { медичний університет }\end{array}$ & $\begin{array}{c}83 \\
(67) \\
\end{array}$ & $5(4)$ & $46(36)$ & 11(8) & - & 19(17) & 2(2) \\
\hline $\begin{array}{l}\text { Вінницький національний } \\
\text { медичний університет } \\
\text { ім. М. І. Пирогова }\end{array}$ & $\begin{array}{c}170 \\
(120)\end{array}$ & $7(6)$ & $16(11)$ & $57(20)$ & $2(2)$ & $10(6)$ & $78(75)$ \\
\hline $\begin{array}{l}\text { Дніпропетровська державна } \\
\text { медична академія }\end{array}$ & $\begin{array}{c}62 \\
(38)\end{array}$ & $5(3)$ & $23(12)$ & $17(11)$ & $6(4)$ & $4(1)$ & $7(7)$ \\
\hline $\begin{array}{l}\text { Донецький національний } \\
\text { медичний університет } \\
\text { iм. М. Горького }\end{array}$ & $\begin{array}{r}2827 \\
(77)\end{array}$ & $4(4)$ & $53(32)$ & - & $67(31)$ & $39(10)$ & 2654 \\
\hline $\begin{array}{l}\text { Запорізький державний } \\
\text { медичний університет }\end{array}$ & $\begin{array}{c}507 \\
(272) \\
\end{array}$ & $5(3)$ & $\begin{array}{l}114 \\
(57)\end{array}$ & $\begin{array}{l}157 \\
(84) \\
\end{array}$ & $3(2)$ & $11(8)$ & $\begin{array}{c}207 \\
(118) \\
\end{array}$ \\
\hline $\begin{array}{l}\text { Івано-Франківський } \\
\text { національний медичний } \\
\text { університет }\end{array}$ & $\begin{array}{l}121 \\
(94)\end{array}$ & $5(5)$ & $8(8)$ & $18(13)$ & $3(2)$ & $3(3)$ & $84(63)$ \\
\hline $\begin{array}{l}\text { Кримський державний } \\
\text { медичний університет } \\
\text { iм. С. І. Георгієвського }\end{array}$ & $\begin{array}{l}106 \\
(24)\end{array}$ & $6(5)$ & $40(3)$ & 19(7) & - & 15 & $26(9)$ \\
\hline $\begin{array}{l}\text { Луганський державний } \\
\text { медичний університет }\end{array}$ & $\begin{array}{c}41 \\
(30) \\
\end{array}$ & $6(4)$ & - & $25(20)$ & - & $1(1)$ & $9(6)$ \\
\hline $\begin{array}{l}\text { Львівський національний } \\
\text { медичний університет } \\
\text { iм. Д. Галицького }\end{array}$ & $\begin{array}{c}187 \\
(165)\end{array}$ & $7(7)$ & $55(49)$ & $6(3)$ & $1(1)$ & $28(26)$ & 90(79) \\
\hline $\begin{array}{l}\text { Національний медичний } \\
\text { університет імені } \\
\text { О. О. Богомольця }\end{array}$ & $\begin{array}{c}162 \\
(110)\end{array}$ & $24(14)$ & $49(33)$ & $41(35)$ & 15(9) & $12(8)$ & 21(11) \\
\hline $\begin{array}{l}\text { Національний фармацевтичний } \\
\text { університет }\end{array}$ & $\begin{array}{l}100 \\
(47)\end{array}$ & $8(4)$ & $48(20)$ & $2(2)$ & $6(5)$ & $10(4)$ & $26(12)$ \\
\hline $\begin{array}{l}\text { Одеський національний } \\
\text { медичний університет }\end{array}$ & $\begin{array}{c}55 \\
(30) \\
\end{array}$ & $3(2)$ & $25(14)$ & $6(6)$ & $7(3)$ & $9(2)$ & $5(3)$ \\
\hline $\begin{array}{l}\text { Тернопільський державний } \\
\text { медичний університет ім. } \\
\text { I. Я. Горбачевського }\end{array}$ & $\begin{array}{c}110 \\
(107)\end{array}$ & $15(14)$ & $12(10)$ & $9(9)$ & $47(47)$ & $8(8)$ & 19(19) \\
\hline $\begin{array}{l}\text { Українська медична } \\
\text { стоматологічна академія }\end{array}$ & $\begin{array}{l}113 \\
(71) \\
\end{array}$ & $4(2)$ & $45(27)$ & $17(11)$ & $7(7)$ & $10(5)$ & $30(19)$ \\
\hline $\begin{array}{l}\text { Харківський національний } \\
\text { медичний університет }\end{array}$ & $\begin{array}{l}207 \\
(79)\end{array}$ & $10(6)$ & $25(7)$ & 10(3) & $4(2)$ & $8(2)$ & $\begin{array}{l}150 \\
(59) \\
\end{array}$ \\
\hline
\end{tabular}

Примітка. Дані в ( ) - видання українською мовою.

Міністерством охорони здоров'я України з метою покращання забезпечення студентів вищих медичних (фармацевтичного) навчальних закладів сучасними підручниками, підготовленими державною мовою відповідно до оновлених навчальних програм, наказом МОЗ України від 22.06.2010 № 502 "Про затвердження робочих груп з питань підготовки національних підручників для студентів вищих навчальних закладів IV рівня акредитації, підпорядкованих МОЗ України”, було доручено провідним фахівцям 
ВМ(Ф)НЗ сформувати авторські колективи для підготовки базових підручників з усіх дисциплін діючих навчальних планів підготовки лікарів та фармацевтів. Оскільки відповідно до чинного законодавства викладання у вищих навчальних закладах здійснюється українською мовою, у вказаному наказі базовий підручник названо національним.

На сьогодні авторські колективи для написання базових підручників сформовані, підготовлені планипроспекти та анотації, на підставі яких складено Перелік державних базових підручників для вищих медичних (фармацевтичного) навчальних закладів України IV рівня акредитації та видання їх протягом 2011 - 2013 рр., який 28 квітня 2011 року затверджений заступником міністра. Авторські колективи працюють над створенням підручників, частина 3 них уже видана.

Міністерством охорони здоров'я України наказом від 23.08.2011 № 532 “Про внесення змін до наказу MO3 України від 26.02.2003 № 86” затверджено оновлений перелік опорних кафедр з усіх дисциплін.
Слід нагадати, що відповідно до Примірного положення основними завданнями, які покладаються на опорні кафедри, $є$ :

- узагальнення та впровадження передового досвіду викладання однопрофільних дисциплін у $\mathrm{BM}(\Phi) \mathrm{H} 3$;

- розробка пропозицій і рекомендацій щодо удосконалення організації та методики підвищення якості підготовки студентів;

- створення та введення у навчальний процес удосконалених навчальних планів і програм міжкафедральних підручників, посібників, навчальних відеофільмів тощо;

- участь у розробці новітніх технологій навчання та державних стандартів освіти.

Таким чином, фахівці опорних кафедр працюють над створенням базових підручників з усіх дисциплін, але виникає закономірне питання - чи будуть виділені бюджетні кошти на їх видання. Протягом останніх останніх чотирьох років ЦМК з ВМО кошти на придбання (видання) підручників не виділялись (табл. 6).

Таблиця 6. Надання коштів ЦМК з ВМО МОЗУ на закупівлю навчальної літератури для студентів BMH3

\begin{tabular}{|c|c|c|c|}
\hline $\begin{array}{c}№ \\
\text { 3a/ח }\end{array}$ & Рік & $\begin{array}{c}\text { Сума } \\
\text { (в тис. грн) }\end{array}$ & Назва підручника \\
\hline 1 & 2006 & 70,0 & “Травматологія і ортопедія” (Скляренко Є. Т. ) видавн. “Здоров’я” \\
\hline 2 & 2007 & 42,1 & $\begin{array}{l}\text { “Онкологія”( Білинський Б. Т., Стернюк Ю. М., Шпарик М. В.) видавн. } \\
\text { "Нова книга”" }\end{array}$ \\
\hline 3 & 2008 & 95,0 & $\begin{array}{c}\text { “Неврологія” ( Вінничук С. М.) видавн. “Здоров’я”, “Шкірні та венеричні } \\
\text { хвороби” (Дудченко М. О.) видавн. “Нова книга” }\end{array}$ \\
\hline 4 & 2009 & 0,0 & \\
\hline 5 & 2010 & 0,0 & \\
\hline 6 & 2011 & 0,0 & \\
\hline
\end{tabular}

Відповідно до кошторису ЦМК з ВМО МОЗУ кошти на придбання підручників виділяються тільки по КЕКВ 2110 (придбання обладнання та предметів довгострокового користування).

Нагадаємо, що наказом Міністерства освіти і науки від 20.12.2010 № 1258 “Щодо плану реалізації завдань, визначених розпорядженням Кабінету Міністрів України від 27 серпня 2010 року № 1728 “Про затвердження плану заходів щодо розвитку вищої освіти на період до 2015 року” (п. 2.) - “Забезпечити видання навчальної літератури для вищих навчальних закладів, у тому числі на електронних носіях".

Необхідно додати, що фахівцями опорних кафедр проводиться також значна робота з розробки Типових навчальних програм 3 дисциплін додипломної підготовки лікарів та фармацевтів. Так, у 2011 році було підготовлено 144 Типові навчальні програми, які затверджені в установленому порядку МО3 України, тиражовані вищими навчальними закладами та направлені у всі ВМ(Ф)НЗ. У 2012 р. доручено фахівцям опорних кафедр розробити ще 135 програм (переважно для спеціальностей “Стоматологія”, “Медична психологія”, “Фармація”). Потребують доопрацювання на виконання оновлених навчальних планів додипломної підготовки фахівців усіх спеціальностей 75 програм.

Висновок. Таким чином, покращання навчальнометодичного забезпечення студентів вищих медичних (фармацевтичного) навчальних закладів можливе за умови збільшення видатків навчальних закладів на закупівлю та видання сучасних навчальних книг, оновлення програм з навчальних дисциплін. 


\section{Література}

1. Підаєв А. В. Болонський процес в Свропі. Що таке і чи потрібний він Україні? Чи можлива інтеграція медичної освіти України в Свропейський освітній простір? / А. В. Підаєв, В. Г. Передерій. - Одеса : Одес. держ. мед. ун-т, 2004.- $190 \mathrm{c}$.

2. Створення сучасного підручника - запорука підвищення ефективності навчального процесу / О. П. Волосовець, Ю. С. П'ятницький, І. С. Вітенко, І. В. Мельник // М-ли Всеукр. наук. навч.-метод. конф. "Нові напрямки впровадження кредитно-модульної системи організації навчаль- ного процесу у вищих медичних і фармацевтичному навчальних закладах України III-IV рівнів акредитації'. - Тернопіль : Укрмедкнига, 2011.-С. 14-18.

3. Вітенко I. С. Вимоги до сучасного українського підручника / І. С. Вітенко, І. В. Мельник, С. В. Штанько // М-ли Всеукр. наук. навч.-метод. конф. "Нові напрямки впровадження кредитно-модульної системи організації навчального процесу у вищих медичних і фармацевтичному навчальних закладах України III-IV рівнів акредитації'. - Тернопіль : Укрмедкнига, 2011.-С. 18-19. 